\title{
Efektivitas Layanan Konseling Behavioral dengan Teknik Self-Management untuk Mengembangkan Tanggung Jawab Belajar pada Peserta Didik Kelas XI SMA Al-Azhar 3 Bandar Lampung Tahun Ajaran 2015/2016
}

\author{
Mega Aria Monica, Ruslan Abdul Gani
}

Dosen Fakultas Tarbiyah dan Keguruan, IAIN Raden Intan Lampung

Diterima: 27 Januari 2016. Disetujui: 12 Maret 2016. Dipublikasikan: Mei 2016

\begin{abstract}
Abstrak: Tanggung jawab belajar adalah suatu proses di mana seseorang berinteraksi langsung menggunakan semua alat inderanya terhadap objek belajar dan lingkungan melalui pendidikan di sekolah yang menghasilkan perubahan tingkah laku seperti pengetahuan, cara berpikir, ketrampilan, sikap, nilai dan kesediaan menanggung segala akibat dari kegiatan belajar dengan penuh kesadaran, kerelaan, rasa memiliki, dan disiplin yang bertujuan untuk menguasai materi ilmu pengetahuan. Tujuan dari penelitian ini yaitu untuk mengetahui apakah konseling behavioral dengan teknik self- management efektif untuk mengembangkan tanggung jawab belajar peserta didik kelas XI SMA Al-Azhar 3 Bandar Lampung tahun ajaran 2016/2017. Desain eksperimen quasi yang digunakan adalah nonequlvalent pretest-postest group design, yaitu jenis desain yang biasanya dipakai pada eksperimen yang menggunakan kelas-kelas yang sudah ada sebagai kelompoknya, dengan memilih kelas-kelas yang diperkirakan sama keadaan atau kondisinya. Sampel penelitian ini adalah peserta didik kelas XI SMA Al-Azhar 3 Bandar Lampung yang memiliki kategori tanggung jawab belajar tinggi sedang dan rendah.Berdasarkan hasil penelitian, diketahui bahwa terdapat perkembangan tanggung jawab belajar peserta didik setelah melaksanakan layanan behavioral dengan teknik self-management dengan diperoleh (df) 78 kemudian dibandingkan dengan ttabel $0,05=2,101$, maka thitung $\geq$ tabel $(3,679 \geq 2,101)$ atau nilai sign.(2- tailed) lebih kecil dari nilai kritik $0,005(0.000 \leq 0,005)$, ini menunjukkan bahwa $\mathrm{H}_{\mathrm{O}}$ ditolak dan $\mathrm{Ha}$ diterima, selain itu didapatkan nilai rata-rata kelompok eksperimen lebih besar dari pada kelompok kontrol (115.275 $\geq 101.925)$. Jadi dapat disimpulkan bahwa layanan konseling behavioral dengan teknik self-management dapat mengembangkan tanggung jawab belajar pada peserta didik kelas XI SMA Al-Azhar 3 Bandar Lampung Tahun Ajaran 2016/2017.
\end{abstract}

Kata Kunci: Tanggung Jawab Belajar; Self-Management; Layanan Konseling Behavioral

\section{Pendahuluan}

Dalam bimbingan dan konseling terdapat empat bidang bimbingan salah satunya bidang belajar di mana masalah belajar merupakan inti dari kegiatan di sekolah. Sebab semua di sekolah diperuntukan bagi berhasilnya proses belajar bagi setiap peserta didik yang sedang study di sekolah tersebut. Oleh karena itu memberikan layanan bimbingan di sekolah berarti pula memberikan pelayanan belajar bagi setiap peserta didik.

Seseorang yang dilandasi dengan rasa tanggung jawab, maka ia dapat meningkatkan perkembangan potensinyamelalui belajar sesuai dengan harapan dan keinginan dirinya sendiri maupun lingkungan sekitar. Sikap tanggung jawab belajar tersebut dapat dicirikan seperti:

1. Melakukan tugas belajar dengan rutin tanpa harus diberi tahu

2. Dapat menjelaskan alasan atas belajar yang dilakukannya

3. Tidak menyalahkan orang lain dalam belajar

4. Mampu menentukan pilihan kegiatan belajar dari beberapa alternative

5. Menghormati dan menghargai aturan di sekolah (http://ppb.jurnal.unesa.ac.id/130_891).

Apabila tanggung jawab belajar tersebut tidak ditingkatkan maka hal ini akan berakibat pada menurunnya hasil belajar peserta didik, tidak tercapainya perkembangan potensi dengan baik kebiasaan kurangnya kedisiplinan diri, dan bahkan peserta didik tidak naik kelas. Agar peserta didik tidak mengalami hal tersebut, maka guru BK sebagai pendidik juga harus bisa membantu menanamkan sikap tanggung jawab belajar kepada peserta didiknya melalui keahlian yang dimilikinya. Dengan menggunakan konseling behavioral diharapkan kepribadian yang bertanggung jawab dalam belajar peserta didik dapat dikembangkan. 


\section{A. Konseling Behavioral dengan Teknik Self-Management}

1. Konseling Behavioral (Behavioral Therapy)

Konseling behavioral adalah suatu teknik terapi dalam konseling yang berlandaskan teori belajar yang berfokus pada tingkah laku individu untuk membantu konseli mempelajari tingkah laku baru dalam memecahkan masalahnya melalui teknik-teknik yang berorientasi tindakan.

2. Teknik Self-Management

Salah satu teknik yang dipilih

peneliti dalam konseling behavioral adalah teknik self-management. Peneliti memilih teknik self-management dalam meningkatkan tanggung jawab belajar peserta didik dengan alasan karena teknik ini bertujuan untuk membantu konseli dalam mengatur, memantau, dan mengevaluasi dirinya sendiri dalam mencapai perubahan tingkah laku ke arah yang lebih baik yaitu peserta didik dapat bertanggung jawab dalam belajarnya.

a. Konsep Dasar

Istilah self-management mengacu pada harapan agar konseli dapat lebih aktif dalam proses terapi (Hartono dan Soedarmadji, 2005: 125). Sama halnya dengan kemampuan mengatur diri dan mengarahkan diri. Kemampuan mengatur diri dapat mencegah individu dari keadaan malasuai atau penyimpangan kepribadian. Dalam penggunaan strategi ini diharapkan konseli dapat mengatur, memantau dan mengevaluasi dirinya sendiri untuk mencapai perubahan kebiasaan tingkah laku yang lebih baik.

b. Tujuan

Tujuan dari pengelolaan diri yaitu untuk mengatur perilakunya sendiri yang bermasalah pada diri sendiri maupun orang lain.

c. Manfaat

Dalam penerapan teknik pengelolaan diri (self management) tanggung jawab keberhasilan konseling berada di tangan konseli. Konselor berperan sebagai pencetus gagasan, fasilitator yang membantu merancang program serta motivator bagi konseli (Hartono dan Soedarmadji, 2005: 181).

d. Peran Konselor dan Konseli

Seperti yang telah kita ketahui, bahwa dalam konseling behavior peran konselor adalah sebagai guru, mentor, fasilitator dan pemberi dukungan kepada konseli dalam mengarahkan konseli untuk mencapai tujuannya. Sebaliknya peran konseli dalam mengikuti teknik self-management juga diharapkan harus lebih aktif dalam proses konseling.

e. Faktor-faktor keefektifan dalam pelaksanaan teknik self-management Agar pelaksanaan strategi self- management dapat dilaksanakan secara efektif, maka ada beberapa faktor yang perlu diperhatikan, yaitu:

1. adanya kombinasi beberapa strategi konseling di mana beberapa diantaranya berfokus pada antecedent dan yang lainnya pada konsekuensi dari perilaku tertentu;

2. konsistensi penggunaan salah satu strategi dalam kurun waktu tertentu;

3. bukti evaluasi diri sendiri, penentuan sasaran dengan standar tinggi;

4. gunakan self-management secara tertutup, verbal atau dengan bentuk materimateri tertentu; dan

5. 5)adanya dukungan eksternal/lingkungan (Hartono dan Soedarmadji, 2005: 126).

f. Langkah-langkah self-management Adapun tahap-tahap self-Management (Pengelolaan diri) menurut Sukadji adalah sebagai berikut:

1. self-monitoring (monitor diri) atau observasi diri

2. self-evaluation (evalusi diri)

3. self-reinforcement (pemberian penguatan, penghapusan atau hukuman)

4. Target Behavior 


\section{B. Tanggung Jawab Belajar}

1. Konsep Tanggung Jawab Belajar

Tanggung jawab belajar adalah suatu proses dimana seseorang berinteraksi langsung menggunakan semua alat inderanya terhadap objek belajar dan lingkungan melalui pendidikan di sekolah yang menghasilkan perubahan tingkah laku seperti pengetahuan, cara berpikir, ketrampilan, sikap, nilai dan kesediaan menanggung segala akibat dari kegiatan belajar dengan penuh kesadaran, kerelaan, rasa memiliki, dan disiplin yang bertujuan untuk menguasai materi ilmu pengetahuan.

\section{Ciri-ciri Tanggung Jawab Belajar}

Secara umum peserta didik yang

bertanggung jawab terhadap belajar dapat dilihat dari ciri-ciri sebagai berikut:

1) Akan senantiasa mengerjakan tugas- tugas yang diberikan oleh gurunya sampai tuntas baik itu tugas yangdiberikan di sekolah maupun PR yang harus mereka kerjakan di rumah.

2) Selalu berusaha menghasilkan sesuatu tanpa rasa lelah dan putus asa.

3) Selalu berpikiran positif disetiap kesempatan dan dalam situasi apapun.

4) Tidak pernah menyalahkan orang lain atas kesalahan yang telah diperbuatnya (http://ejournal.unidiksha.ac.id/inde x.php/JJBK/article/view/762).

3. Faktor-faktor RendahnyaTanggung Jawab Belajar

Menurut pendapat Sudani, dkk dalam jurnalnya menyebutkan bahwa: Pada dasarnya, perilaku tanggung jawab belajar peserta didik yang rendah dipengaruhi oleh beberapa faktor antara lain yaitu: (1) kurangnya kesadaran peserta didik tersebut akan pentingnya melaksanakan hak dan kewajiban yang merupakan tanggung jawabnya, (2) kurang memiliki rasa percaya diri terhadap kemampuan yang dimiliki, dan (3) layanan bimbingan konseling yang dilakukan oleh guru BK dalam menangani perilaku tanggung jawab belajar secara khusus belum terlaksana secara optimal di kelas (http://ejournal.unidiksha.ac.id/index.ph p/JJBK/article/view/765/638). 4. Dinamika Tanggung Jawab Belajar

Dinamika merupakan sesuatu yang mengandung arti selalu bergerak, berkembang ataupun keadaan yang berhubungan dengan perubahan. Sedangkan dinamika tanggung jawab belajar, berarti perubahan peserta didik yang sebelumnya kurang bertanggung jawab terhadap belajar berubah menjadi adanya peningkatan dalam tanggung jawab belajar seorang peserta didik (http://ejournal.unidiksha.ac.id/index.ph p/JJBK/article/view/765/638). Apabila tanggung jawab belajar tersebut tidakditingkatkan maka hal ini akan berakibat pada menurunnya hasil belajar peserta didik, tidak tercapainya perkembangan potensi dengan baik, dan kebiasaan kurangnya kedisiplinan diri. Agar peserta didik tidak mengalami hal tersebut, maka konselor sebagai pendidik harus bisa membantu peserta didik dalam meningkatkan tanggung jawab belajarnya. Peneliti berpandangan bahwa dengan menggunakan teknik self- management, peserta didik dapat mengontrol dirinya untuk belajar.

\section{Jenis-jenis Tanggung Jawab Belajar}

Menurut Tirtorahardjo, tanggung jawab berdasarkan wujudnya terdiri dari: (1) tanggung jawab kepada diri sendiri, (2) tanggung jawab kepada masyarakat, dan (3) tanggung jawab kepada Tuhan (Tirtarahardja, Umar dan Sulo, 2005:. 8). Berikut penjelasan dari ketiga jenis tanggung jawab berdasarkan wujudnya:

\section{Mengembangkan Tanggung Jawab Belajar Dengan Layanan Konseling Behavioral dengan Teknik Self-Management}

Dalam pendekatan behavioral terdapat beberapa teknik khusus, salah satu teknik yang dipilih oleh peneliti yaitu teknik self-management (pengelolaan diri). Pengelolaan diri (self management) merupakan teknik terapi dalam konseling behavior yang membantu konseli 
untuk dapat mengatur, memantau dan mengevaluasi dirinya sendiri dalam mencapai perubahan kebiasaan tingkah laku yang lebih baik melalui tahap menentukan perilaku sasaran, memonitor perilaku tersebut, memilih prosedur tersebut, dan mengevaluasi efektivitas prosedur tersebut.

Teknik self-management menunjuk pada suatu teknik dalam terapi kognitif-behavior yang dirancang untuk membantu konseli mengontrol dan mengubah tingkah lakunya sendiri ke arah yang lebih positif. Peneliti akan menangani tanggung jawab belajar peserta didik dengan cara mengatur perilaku peserta diidk agar mampu mengelola perilaku, pikiran, dan perasaan dalam diri untuk mencapai tujuan tertentu, yaitu mempunyai tanggung jawab belajar. Dalam melaksanakan teknik self-management, konselor membantu konseli dalam menyusun rencana yang meliputi pemantauan diri (self-monitoring), penilaian diri (self-evaluation), penguatan diri (self-reinforcement) dan sasaran perilaku (target behavior) (Gunarsa, 2004: 224). Penggunaan strategi ini diharapkan peserta didik mengatur, memantau dan mengevaluasi dirinya sendiri untuk mencapai perubahan kebiasaan yang lebih baik.

\section{Metode Penelitian}

Penelitian menggunakan pendekatan kuantitatif yaitu suatu jenis penelitian ilmiah di mana peneliti memutuskan apa yang akan diteliti dengan cara mengajukan pertanyaanpertanyaan yang spesifik atau sempit, mengumpulkan data-data yang dapat dikuantifikasikan, menganalisis angka-angka tersebut dengan menggunakan statistik dan melakukan penelitian dalam suatu cara yang objektif (Sugiyono, 2010: 107).

Metode penelitian yang digunakan adalah metode eksperimen quasi. Penelitian eksperimen quasi yaitu rancangan penelitian eksperimen tapi tidak dapat berfungsi sepenuhnya untuk mengontrol atau mengendalikan variabel-variabel luar yang dapat mempengaruhi eksperimen. Pada eksperimen quasi tidak dilakukan dengan teknik random (random assignment) melainkan pengelompokan berdasarkan kelompok yang terbentuk sebelumnya (Sugiyono, 2010: 109).

\section{Hasil dan Pembahasan}

1. Profil Umum Tanggung Jawab Belajar pada Peserta Didik

Dalam pelaksanaan teknik self- management peneliti mengunakan sampel peserta didik kelas XI IPA yang terdiri dari kelompok eksperimen dan kelompok kontrol. Sebelum memberikan teknik self-management untuk mengembangkan tanggung jawab belajar peneliti terlebih dahulu menentukan peserta didik yang akan menjadi subjek dalam penelitian berdasarkan hasil pra penelitian dan rekomendasi guru BK kemudian melakukan penyebaran instrumen penelitian tanggung jawab belajar terhadap peserta didik kelas XI IPA 1 dan XI IPA 2 SMA Al-azhar 3 Bandar Lampung Tahun Ajaran 2016/2017, diperoleh persentase tanggung jawab belajar peserta didik yang selanjutnya dikategorikan dalam lima kategori sebagaimana yang terdapat pada Tabel 1 sebagai berikut.

Tabel 1. Kategori Penilaian Tingkat Tanggung Jawab Belajar

\begin{tabular}{|c|c|c|c|c|}
\hline No & Skor & F & \% & Kategori \\
\hline 1 & $148-175$ & 0 & 0 & Sangat Tinggi \\
\hline 2 & $120-147$ & 8 & $10 \%$ & Tinggi \\
\hline 3 & $92-119$ & 22 & $27,5 \%$ & Sedang \\
\hline 4 & $64-91$ & 50 & $62,5 \%$ & Rendah \\
\hline 5 & $35-63$ & 0 & 0 & Sangat Rendah \\
\hline & Jumlah & 80 & $100 \%$ & \\
\hline
\end{tabular}




\section{Deskripsi Data}

a. Hasil Pretest Tanggung Jawab Belajar pada Peserta Didik

Pretest dilakukan dengan tujuan untuk mengetahui gambaran awal kondisi tanggung jawab belajar pesertadidik sebelum diberi perlakuan. Pretest diberikan kepada seluruh peserta didik kelas XI IPA 1 dan IPA 2 di SMA Al- Azhar 3 Bandar Lampung. Berdasarkan hasil pretest peserta didik dengan berbagai kategori terdapat pada tabel 2:

Tabel 2. Hasil Pretest Kelompok Eksperimen Peserta Didik Kelas XI IPA 2

\begin{tabular}{|c|c|c|c|}
\hline No & Peserta didik & Hasil Pretest & Kategori \\
\hline 1 & Konseli 1 & 85 & Rendah \\
\hline 2 & Konseli 2 & 84 & Rendah \\
\hline 3 & Konseli 3 & 79 & Rendah \\
\hline 4 & Konseli 4 & 120 & Tinggi \\
\hline 5 & Konseli 5 & 78 & Rendah \\
\hline 6 & Konseli 6 & 82 & Rendah \\
\hline 7 & Konseli 7 & 84 & Rendah \\
\hline 8 & Konseli 8 & 85 & Rendah \\
\hline 9 & Konseli 9 & 87 & Rendah \\
\hline 10 & Konseli 10 & 93 & Sedang \\
\hline 11 & Konseli 11 & 101 & Sedang \\
\hline 12 & Konseli 12 & 88 & Rendah \\
\hline 13 & Konseli 13 & 90 & Sedang \\
\hline 14 & Konseli 14 & 78 & Rendah \\
\hline 15 & Konseli 15 & 75 & Rendah \\
\hline 16 & Konseli 16 & 85 & Rendah \\
\hline 17 & Konseli 17 & 71 & Rendah \\
\hline 18 & Konseli 18 & 120 & Tinggi \\
\hline 19 & Konseli 19 & 88 & Rendah \\
\hline 20 & Konseli 20 & 98 & Sedang \\
\hline 21 & Konseli 21 & 126 & Tinggi \\
\hline 22 & Konseli 22 & 105 & Sedang \\
\hline 23 & Konseli 23 & 87 & Rendah \\
\hline 24 & Konseli 24 & 76 & Rendah \\
\hline 25 & Konseli 25 & 74 & Rendah \\
\hline 26 & Konseli 26 & 89 & Rendah \\
\hline 27 & Konseli 27 & 95 & Sedang \\
\hline 28 & Konseli 28 & 121 & Tinggi \\
\hline 29 & Konseli 29 & 123 & Tinggi \\
\hline 30 & Konseli 30 & 87 & Rendah \\
\hline 31 & Konseli 31 & 83 & Rendah \\
\hline 32 & Konseli 32 & 76 & Rendah \\
\hline 33 & Konseli 33 & 85 & Rendah \\
\hline 34 & Konseli 34 & 88 & Rendah \\
\hline 35 & Konseli 35 & 79 & Rendah \\
\hline 36 & Konseli 36 & 84 & Rendah \\
\hline 37 & Konseli 37 & 81 & Rendah \\
\hline 38 & Konseli 38 & 105 & Sedang \\
\hline 39 & Konseli 39 & 87 & Rendah \\
\hline 40 & Konseli 40 & 85 & Rendah \\
\hline \multicolumn{2}{|c|}{$\mathrm{N}^{\mathrm{B}}=40$} & $\sum 3607$ & \\
\hline \multicolumn{2}{|c|}{ Mean / Rata-rata } & 90.17 & \\
\hline
\end{tabular}

Berdasarkan tabel 2 dapat diketahui bahwa ada 40 (empat puluh) peserta didik yang memiliki kategori rendah, sedang dan tinggi dalam tanggung jawab belajar, yaitu terdapat 29 konseli dengan kategori rendah, 6 konseli dengan kategori sedang dan 5 konseli dengan kategori tinggi, adapun skor rata-rata yakni 90.17. Kemudian peneliti memberikan treatment (perlakuan) teknik self-management untuk mengembangkan tanggung jawab belajar. 
Sedangkan untuk hasil pretest kelompok kontrol kelas XI IPA 1 SMA Al-Azhar 3 Bandar Lampung dipaparkan pada table 3.

Tabel 3. Hasil Pretest Kelompok Kontrol Peserta Didik Kelas XI IPA 1

\begin{tabular}{|c|c|c|c|}
\hline No & Peserta didik & Hasil Pretest & Kategori \\
\hline 1 & Konseli 1 & 94 & Sedang \\
\hline 2 & Konseli 2 & 83 & Rendah \\
\hline 3 & Konseli 3 & 92 & Sedang \\
\hline 4 & Konseli 4 & 73 & Rendah \\
\hline 5 & Konseli 5 & 78 & Rendah \\
\hline 6 & Konseli 6 & 72 & Rendah \\
\hline 7 & Konseli 7 & 94 & Sedang \\
\hline 8 & Konseli 8 & 85 & Rendah \\
\hline 9 & Konseli 9 & 78 & Rendah \\
\hline 10 & Konseli 10 & 95 & Sedang \\
\hline 11 & Konseli 11 & 106 & Sedang \\
\hline 12 & Konseli 12 & 98 & Sedang \\
\hline 13 & Konseli 13 & 101 & Sedang \\
\hline 14 & Konseli 14 & 86 & Rendah \\
\hline 15 & Konseli 15 & 77 & Rendah \\
\hline 16 & Konseli 16 & 86 & Rendah \\
\hline 17 & Konseli 17 & 78 & Rendah \\
\hline 18 & Konseli 18 & 125 & Tinggi \\
\hline 19 & Konseli 19 & 98 & Sedang \\
\hline 20 & Konseli 20 & 109 & Sedang \\
\hline 21 & Konseli 21 & 90 & Sedang \\
\hline 22 & Konseli 22 & 128 & Tinggi \\
\hline 23 & Konseli 23 & 85 & Rendah \\
\hline 24 & Konseli 24 & 86 & Rendah \\
\hline 25 & Konseli 25 & 84 & Rendah \\
\hline 26 & Konseli 26 & 90 & Sedang \\
\hline 27 & Konseli 27 & 95 & Sedang \\
\hline 28 & Konseli 28 & 89 & Rendah \\
\hline 29 & Konseli 29 & 108 & Sedang \\
\hline 30 & Konseli 30 & 127 & Tinggi \\
\hline 31 & Konseli 31 & 85 & Rendah \\
\hline 32 & Konseli 32 & 77 & Rendah \\
\hline 33 & Konseli 33 & 83 & Rendah \\
\hline 34 & Konseli 34 & 82 & Rendah \\
\hline 35 & Konseli 35 & 91 & Sedang \\
\hline 36 & Konseli 36 & 82 & Rendah \\
\hline 37 & Konseli 37 & 83 & Rendah \\
\hline 38 & Konseli 38 & 81 & Rendah \\
\hline 39 & Konseli 39 & 90 & Sedang \\
\hline 40 & Konseli 40 & 84 & Rendah \\
\hline \multicolumn{2}{|c|}{$\mathrm{N}=40$} & $\sum$ & \\
\hline \multicolumn{2}{|c|}{ Mean / Rata-rata } & 90,7 & \\
\hline
\end{tabular}

Berdasarkan tabel 3 dapat diketahui bahwa ada 40 (empat puluh) peserta didik yang memiliki kategori rendah, sedang dan tinggi dalam tanggung jawab belajar, yaitu terdapat 21 konseli dengan kategori rendah, 16 konseli dengan kategori sedang dan 3 konseli dengan kategori tinggi, adapun skor rata-rata yakni 90.7. Kemudian peneliti memberikan treatment (perlakuan) teknik self-management untuk mengembangkan tanggung jawab belajar. 
b. Hasil Posttest Tanggung Jawab Belajar pada Peserta Didik

Untuk melihat perubahan pada peserta didik terkait layanan konseling behavioral dengan teknik self-management untuk mengembangkan tanggung jawab belajar. berdasarkan hasil posttest kelompok eksperimen pada tabel 4 sebagai berikut:

Tabel 4. Data Hasil Posttest Kelompok Eksperimen kelas XI IPA 2

\begin{tabular}{|c|c|c|c|}
\hline No & Peserta didik & Hasil Pretest & Kategori \\
\hline 1 & Konseli 1 & 105 & Sedang \\
\hline 2 & Konseli 2 & 121 & Tinggi \\
\hline 3 & Konseli 3 & 109 & Sedang \\
\hline 4 & Konseli 4 & 148 & Sangat Tinggi \\
\hline 5 & Konseli 5 & 109 & Sedang \\
\hline 6 & Konseli 6 & 120 & Tinggi \\
\hline 7 & Konseli 7 & 106 & Sedang \\
\hline 8 & Konseli 8 & 121 & Tinggi \\
\hline 9 & Konseli 9 & 109 & Sedang \\
\hline 10 & Konseli 10 & 151 & Sangat Tinggi \\
\hline 11 & Konseli 11 & 128 & Tinggi \\
\hline 12 & Konseli 12 & 89 & Rendah \\
\hline 13 & Konseli 13 & 121 & Tinggi \\
\hline 14 & Konseli 14 & 86 & Rendah \\
\hline 15 & Konseli 15 & 105 & Sedang \\
\hline 16 & Konseli 16 & 121 & Tinggi \\
\hline 17 & Konseli 17 & 109 & Sedang \\
\hline 18 & Konseli 18 & 148 & Sangat Tinggi \\
\hline 19 & Konseli 19 & 108 & Rendah \\
\hline 20 & Konseli 20 & 135 & Tinggi \\
\hline 21 & Konseli 21 & 147 & Tinggi \\
\hline 22 & Konseli 22 & 130 & Tinggi \\
\hline 23 & Konseli 23 & 124 & Tinggi \\
\hline 24 & Konseli 24 & 95 & Sedang \\
\hline 25 & Konseli 25 & 89 & Rendah \\
\hline 26 & Konseli 26 & 108 & Sedang \\
\hline 27 & Konseli 27 & 125 & Tinggi \\
\hline 28 & Konseli 28 & 140 & Tinggi \\
\hline 29 & Konseli 29 & 132 & Tinggi \\
\hline 30 & Konseli 30 & 116 & Tinggi \\
\hline 31 & Konseli 31 & 92 & Sedang \\
\hline 32 & Konseli 32 & 87 & Rendah \\
\hline 33 & Konseli 33 & 98 & Sedang \\
\hline 34 & Konseli 34 & 111 & Sedang \\
\hline 35 & Konseli 35 & 98 & Sedang \\
\hline 36 & Konseli 36 & 108 & Sedang \\
\hline 37 & Konseli 37 & 105 & Sedang \\
\hline 38 & Konseli 38 & 135 & Tinggi \\
\hline 39 & Konseli 39 & 117 & Sedang \\
\hline 40 & Konseli 40 & 105 & Sedang \\
\hline \multicolumn{2}{|c|}{$\mathrm{N}=40$} & $\sum 4611$ & \\
\hline \multicolumn{2}{|c|}{ Mean/ Rata- Rata } & 115,27 & \\
\hline
\end{tabular}

Berdasarkan tabel 4 dapat diketahui bahwa ada 40 (empat puluh) peserta didik yang telah di berikan perlakuan teknik self-management mengalami perubahan. Hasil dapat diamati dari kategori memiliki kategori rendah, sedang, tinggi dan sangat tinggi dalam tanggung jawab belajar, yaitu terdapat 5 konseli dengan kategori rendah, 17 konseli dengan kategori sedang, 15 konseli dengan kategori tinggi dan 3 konseli dengan kategori sangat tinggi. Hasil nilai rata-rata posttest kelas eksperimen 115.27. Sedangkan untuk melihat perubahan tanggung jawab belajar berdasarkan hasil posttest kelompok kontrol pada tabel 5 sebagai berikut: 
Tabel 5. Data Hasil Posttest Kelompok Kontrol Kelas Kontrol XI IPA 1

\begin{tabular}{|c|c|c|c|}
\hline No & Peserta didik & Hasil Posttest & Kategori \\
\hline 1 & Konseli 1 & 101 & Sedang \\
\hline 2 & Konseli 2 & 90 & Rendah \\
\hline 3 & Konseli 3 & 111 & Sedang \\
\hline 4 & Konseli 4 & 82 & Rendah \\
\hline 5 & Konseli 5 & 83 & Rendah \\
\hline 6 & Konseli 6 & 87 & Rendah \\
\hline 7 & Konseli 7 & 126 & Tinggi \\
\hline 8 & Konseli 8 & 93 & Sedang \\
\hline 9 & Konseli 9 & 89 & Rendah \\
\hline 10 & Konseli 10 & 122 & Tinggi \\
\hline 11 & Konseli 11 & 109 & Sedang \\
\hline 12 & Konseli 12 & 109 & Sedang \\
\hline 13 & Konseli 13 & 118 & Sedang \\
\hline 14 & Konseli 14 & 92 & Sedang \\
\hline 15 & Konseli 15 & 85 & Rendah \\
\hline 16 & Konseli 16 & 96 & Sedang \\
\hline 17 & Konseli 17 & 86 & Rendah \\
\hline 18 & Konseli 18 & 135 & Tinggi \\
\hline 19 & Konseli 19 & 107 & Sedang \\
\hline 20 & Konseli 20 & 120 & Tinggi \\
\hline 21 & Konseli 21 & 99 & Sedang \\
\hline 22 & Konseli 22 & 138 & Tinggi \\
\hline 23 & Konseli 23 & 89 & Rendah \\
\hline 24 & Konseli 24 & 96 & Sedang \\
\hline 25 & Konseli 25 & 93 & Sedang \\
\hline 26 & Konseli 26 & 97 & Sedang \\
\hline 27 & Konseli 27 & 105 & Sedang \\
\hline 28 & Konseli 28 & 109 & Sedang \\
\hline 29 & Konseli 29 & 115 & Tinggi \\
\hline 30 & Konseli 30 & 147 & Sangat Tinggi \\
\hline 31 & Konseli 31 & 89 & Rendah \\
\hline 32 & Konseli 32 & 83 & Rendah \\
\hline 33 & Konseli 33 & 94 & Sedang \\
\hline 34 & Konseli 34 & 87 & Rendah \\
\hline 35 & Konseli 35 & 114 & Sedang \\
\hline 36 & Konseli 36 & 96 & Sedang \\
\hline 37 & Konseli 37 & 92 & Sedang \\
\hline 38 & Konseli 38 & 94 & Sedang \\
\hline 39 & Konseli 39 & 110 & Sedang \\
\hline 40 & Konseli 40 & 89 & Rendah \\
\hline \multirow{2}{*}{\multicolumn{2}{|c|}{$\mathrm{N}=40$}} & $\sum 4077$ & \\
\hline & & 101,92 & \\
\hline
\end{tabular}

Berdasarkan tabel 5 dapat diketahui bahwa ada 40 (empat puluh) peserta didik yang telah di berikan perlakuan teknik self-management mengalami perubahan. Hasil dapat diamati dari kategori memiliki kategori rendah, sedang, tinggi dan sangat tinggi dalam tanggung jawab belajar, yaitu terdapat 12 konseli dengan kategori rendah, 21 konseli dengan kategori sedang, 6 konseli dengan kategori tinggi dan 1 konseli dengan kategori sangat tinggi. Hasil nilai rata-rata posttest kelas eksperimen 101.92.

A. Implementasi Pelaksanaan Layanan Konseling Behavioral dengan Teknik Selfmanagement untuk Mengembangkan Tanggung Jawab Belajar Peserta Didik di SMA AlAzhar 3 Bandar Lampung Tahun Ajaran 2016/2017 
Pelaksanaan kegiatan intervensi teknik self-management untuk mengembangkan tanggung jawab belajar peserta didik dilaksanakan selama 1 kali dalam seminggu. Peserta didik diberikan homework (membuat manajemen waktu dan dream book) sebagai penguatan untuk melakukan perubahan terhadap tanggung jawab belajar peserta didik. Homework berfungsi sebagai alat evaluasi untuk melihat keberhasilan setiap sesi yang telah dilaksanakan. Sebelum memulai sesi konseling dengan mengunakan teknik self-management, peneliti bersama peserta didik melakukan kontrak/komitmen kelompok guna menjalin komitmen untuk melaksanakan pertemuan- pertemuan konseling, kontrak juga dilaksanakan dalam rangka membangun rapport dengan seluruh peserta didik yang menjadi subjek penelitian. Kontrak/komitmen kelompok dimulai dengan mengumpulkan peserta didik-peserta didik yang termasuk pada kategori tanggung jawab belajar tinggi, sedang dan rendah. konselor (peneliti) mengemukakan deskripsi program konseling yang meliputi: tujuan konseling, proses konseling dan sasaran konseling. Peserta didik berjumlah 40 baik itu kelas eksperimen maupun kelas kontrol menyatakan kesediaannya untuk mengikuti program konseling. Kesediaan peserta didik untuk mengikuti program konseling dinyatakan dengan mengisi formulir kontrak/ komitmen kelompok. Adapun deksripsi proses pelaksanaan kegiatan intervensi melalui teknik selfmanagement untuk mengembangkan tanggung jawab belajar peserta didik kelas XI SMA AlAzhar 3 Bandar Lampung tahun ajaran 2016/2017, yaitu sebagai berikut.

a) Kelompok Eksperimen

1. Pertemuan pertama

Hari/Tanggal: Sabtu, 24 September 2016

Waktu: 09.00-09.45 WIB Tempat: Ruang Kelas XI IPA 2

Kegiatan bimbingan konseling dengan teknik self- management dimuali dengan mengucapkan salam. Pemateri (peneliti) mengucapkan terimakasih kepada seluruh peserta didik atas kesediaannya untuk mengikuti bimbingan konseling dengan teknik self-management. Pemateri (peneliti) memimpin doa dengan harapan supaya pelaksanaan bimbingan konseling dapat berjalan dengan lancar dan memberikan manfaat. Pemateri mengawali untuk memulai perkenalan yang dilanjutkan oleh seluruh peserta didik dengan cara bermain game "maju kena mundur kena" secara bergantian meliputi nama, alamat dan hobi. Kegiatan selanjutnya yaitu melakukan penstrukturan dengan menjelasakan pengertian, tujuan, manfaat, azas, norma, cara pelaksanaan kegiatan teknik self-management. Pada tahap pemulaan ini peserta didik terlihat cukup antusias. Selanjutnya pemateri bersama dengan para peserta didik menetapkan kontrak waktu untuk melaksanakan konseling behavioral dengan teknik self-management, waktu yang disepakati sekitar 45 menit untuk pertemuan bimbingan konseling pada pertemuan pertama ini.

Selanjutnyua pemateri (peneliti) mencoba menjelaskan kembali maksud dan tujuan dari pelaksanaan bimbingan konseling teknik self-management. Pemateri menanyakan kesiapan kepada seluruh peserta didik untuk memasuki tahap selanjutnya yakni tahap inti dalam teknik self- management (tahap monitoring). Setelah dipastikan bahwa peserta didik terlihat siap untuk melangkah menuju tahap selanjutnya, kegiatan teknik self- management pun dilanjutkan. Pada pertemuan pertama ini, peneliti tidak langsung masuk pada pengungkapan masalah namun khusus untuk melakukan pembahasan tentang layanan konseling behavioral dengan teknik self-management dan dilanjutkan dengan pretest.

Pemateri memberi kesempatan kepada para peserta didik untuk bertanya kembali serta memberi lembar laiseg secara tertulis kepada peserta didik. Selanjutnya. pemateri menanyakan pesan dan kesan anggota secara bergantian serta membahas untuk pertemuan bimbingan konseling berikutnya. Kegiatan bimbingan konseling diakhiri dengan doa dan salam. 
2. Pertemuan ke dua

Hari/Tanggal: Rabu, 28 September 2016

Waktu: 11.00-11.45 WIB Tempat: Ruang Kelas XI IPA 2

Kegiatan bimbingan konseling pada tahap permulaan dibuka dengan mengucapkan salam. Pemateri mengucapkan terimakasih kepada peserta didik atas kesediaanya dan dilanjutkan dengan memimpin doa. Pemimpin membahas secara singkat mengenai kegiatan teknik self- management sebelumnya. Kegiatan selanjutnya yaitu melakukan penstrukturan dengan menjelaskan kembali kepada peserta didik tentang cara pelaksanaan bimbingan konseling teknik self-management.

Selanjutnya pemateri (peneliti) bersama dengan peserta didik menetapkan kontrak waktu. Pada tahap permulaan ini peserta didik terlihat lebih rileks dibandingkan dengan bimbingan konseling sebelumnya. Pada tahap peralihan, pemateri mencoba menjelaskan kembali maksud dan tujuan dari pelaksanaan bimbingan konseling teknik self-management. Setelah peserta didik dipastikan siap untuk melangkah menuju tahap berikutnya, kegiatan bimbingan konseling teknik self- management pun dilanjutkan.

Kegiatan yang dilakukan dalam tahap ini yakni pembahasan topik tugas mengenai permasalahan yang sering dihadapi oleh peserta didik yaitu malas melakukan tugas rutin, kebingungan dalam menjelaskan alasan belajar, menyalahkan orang lain dalam setiap hasil kegiatan belajar apabila hasilnya kurang baik, tidak mampu memilih alternatif kegiatan belajar serta kurangnya rasa menghormati dan menghargai peraturan sekolah. Pembahasan dan pemecahan masalah akan dilakukan oleh para peserta didik sesuai kesepakatan bersama. Peserta didik masih terlihat malu dan takut untuk mengungkapkan permasalahannya. Pemateri berusaha sebisa mungkin dengan meyakinkan kepada para peserta didik bahwa pelaksanaan bimbingan konseling teknik self- management ini dijamin kerahasiaannya. Satu persatu peserta didik bergantian mengungkapkan permasalahan tanggung jawab belajar yang dialaminya meski masih terkesan grogi, untuk itu pemateri memberikan beberapa cuplikan video untuk membangkitkan semangat kepada peserta didik.

Permasalahan merasa malas melaksanakan tugas rutin yang diberikan guru di sekolah. Pemateri memberikan suatu konsep belajar dangan pertama memberi masukkan kepada seluruh peserta didik untuk membuat manajemen waktu untuk mengontrol kegiatan sehari-hari dengan berkomitmen dan bertanggung jawab. Selanjutnya agar kegiatan teknik self-management lebih menarik, pemateri memberikan kesempatan kepada peserta didik untuk membuat manajemen waktu sebaik mungkin kemudian.

Selanjutnya pemateri menyimpulkan seluruh kegiatan bimbingan konseling yang telah berlangsung. Pemateri menyampaikan bahwa kegiatan akan segera diakhiri. Selanjutnya peserta didik diberi lembar laiseg untuk diisi kemudian peserta didik diminta untuk mengungkapkan pesan dan kesan terhadap kegiatan.

bimbingan konseling teknik self- management pertemuan kedua ini. Pemateri bersama dengan peserta didik membahas untuk pelaksanaan bimbingan konseling berikutnya, setelah disepakati bimbingan konseling layanan behavioral dengan teknik selfmanagement ditutup dengan doa dan salam.

3. Pertemuan Ke Tiga

Hari/Tanggal: Selasa, 4 Oktober 2016

Waktu: 09.00-09.45 WIB Tempat: Ruang BK

Pada tahap permulaan bimbingan konseling teknik self- managemnt dibuka dengan salam dan berdoa. Pemateri (peneliti) memberikan penjelasan singkat tentang kegiatan teknik self-management. Pada pertemuan yang ke tiga ini peserta didik menyepakati untuk membahas mengenai topik bebas, yaitu kemalasan melaksanakan tugas rutin secara disiplin dan bertanggung jawab serta tepat waktu. Karena menurut mereka permasalahan yang dialami oleh mereka hampir sama yaitu sama- sama merasa kurang 
menghargai waktu. Masih terdapat beberapa peserta didik masih belum berani mengeluarkan pendapat, sebelum ditanya atau ditunjuk terlebih dahulu. Sehingga dalam teknik self-management (self-reinforcement) ini sebisa mungkin pemateri mendorong aktif peserta didik untuk membantu dan mengeluarkan pendapat terkait pembahasan tersebut. Seperti biasa, kegiatan dilanjutkan dengan menyaksikan beberapa video sebagai pembakar semangat, mencairkan suasana dan membuat suasana menjadi rileks.

Pemateri menanyakan kembali masalah yang dihadapi peserta didik dalam menajalankan manajemen waktu, dari beberapa peserta didik ada yang menyatakan bahwa sedikit kesulitan untuk berkomitmen dan bertanggung jawab dalam mengikuti manajemen waktu. Pemateri pun memeberikan masukkan atau pendapat agar peserta didik yang masih sering kurang berkomitmen agar memberikan reward kepada diri sendiri dan apabila masih sering tidak komitmen maka punishment kepada diri masingmasing.

Pada tahap ini pemateri memberikan penguatan diri (self reinforment) memberikan suatu motivasi dengan memberikan suatu perlakuan melalui media cuplikan film "bruto" yang kemudian dijelaskan sedetail oleh pemateri, tujuannya tak lain yakin agar peserta didik lebih yakin bahwa setiap dalam diri mereka bisa diubah menjadi lebih baik lagi terutama dalam hal tanggung jawab belajar. Peserta didik pun menyaksikan secara saksama.

Pemateri menginformasikan bahwa kegiatan akan segera diakhiri. Peserta didik diminta untuk mengisi lembar laiseg, kemudian pemateri meminta kesan dan pesan dari para peserta didik terkait kegiatan teknik self-management pertemuan ketiga ini. Pemateri menyimpulkan kegiatan yang telah dilalui pada teknik self-management kali ini. Selanjutnya pemateri dan peserta didik membahas waktu dan tempat untuk melaksanakan Layanan konseling behavioral dengan teknik self-management berikutnya. Kegiatan teknik self-management ditutup dengan do'a dan salam.

4. Pertemuan Ke Empat

Hari/Tanggal: Selasa, 13 Oktober 2016

Waktu: 09.00-09.45 WIB Tempat: Ruang Kelas XI IPA 2

Tahap permulaan ini diawali dengan salam dan berdoa bersama. Pemateri menjelaskan kembali mengenai kegiatan bimbingan konseling kepada seluruh peserta didik. Pemateri dan peserta didik menyepakati waktu yang akan ditempuh dalam layanan konseling behavioral dengan teknik self- management yaitu 45 menit. Pada tahap ini pemateri mengulas kembali mengenai kegiatan yang akan ditempuh. Pemateri memastikan kesiapan para peserta didik untuk mengikuti kegiatan selanjutnya. Setelah dapat dipastikan bahwa peserta didik telah siap untuk melanjutkan kegiatan, kegiatan teknik self-management pun dilanjutkan. Pada tahap kegiatan ini seluruh peserta didik membahas dan memecahkan masalah yang telah disepakati bersama. Pertemuan keempat ini target behavior yakni dimana sasara perilaku peseerta didik agar lebih bertanggung jawab dan berkomitmen dalam belajar.

Pada pertemuan keempat ini peserta didik sudah mulai sadar dan mau mengungkapkan pendapatnya terkait pembahasan topik tugas. Setiap peserta didik memberikan motivasi satu sama lain sehingga setiap peserta didik berani untuk memberikan pendapatnya. Pemateri juga memberikan motivasi terhadap semua peserta didik. Kegiatan dihari keempat ini dilanjutkan dengan memberikan suatu penjelasan dengan bantuan media power point, adapaun tema yang diberikan pemateri yakni meledakkan potensi. Peserta didik begitu sangat antusias menyaksikan paparan penejlasan bagaiaman meledakan potensi. Kemudian pemateri juga memberikan suatu saran kepada peserta didik untuk membuat dream book, yaitu kumpulan- kumpulan impian yang di tulis peserta didik sehingga menjadi kenyataan. Sebelum kegiatan ini di tutup peneliti memberikan angket skala pskologi tanggung jawab belajar kepada peserta didik (posttest). 
Pada tahap pengakhiran pemateri menyimpulkan kegiatan yang telah dibahas dalam pertemuan keempat ini. Pemateri meminta kesan dan pesan terkait pelaksanaan bimbingan kelompok serta memberikan lembar laiseg untuk diisi oleh seluruh peserta didik. Pada pertemuan terakhir ini peserta didik dan pemateri (peneliti) secara bersamasama saling menuliskan harapan kepada pemateri (peneliti) dan diakhiri dengan salam dan doa.

b) Kelompok Kontrol.

1. Pertemuan Pertama

Hari/Tanggal: Sabtu, 24 September 2016

Waktu: 11.00-11.45 WIB Tempat: Ruang Kelas XI IPA 1

Tahap permulaan ini diawali dengan salam dan doa. Peneliti (pemateri) menyampaikan sedikit tentang bimbingan konseling. selanjutnya pemateri membahas materi tentang tanggung jawab belajar. Selanjutnya pemateri memberikan penjelasan tentang kegiatan yang akan dilaksanakan pada pertemuan pertama ini dengan metode ceramah dan diskusi. sebelum kepembahasan peneliti memberikan angket skala psikologi kepada peserta didik untuk mengetahui hasil awal (pretest). Pada pertemuan pertama ini peserta didik masih kurang aktif bahkan malu-malu untuk memberikan pendapatnya terkait permasalahan yang sedang dibahas.

Pemateri memberikan tontonan yang berbau motivasi dan penyemangat dalam kehidupan, sehingga peserta didik mengerti akan pentingnya bersyukur dan akan timbul rasa bertanggung jawab dalam melaksanakan kegiatan belajar.

Pada tahap akhir pemateri menyimpulkan kegiatan yang telah ditempuh dengan teknik self- management. Peserta didik diminta untuk memberikan pesan dan kesan serta mengisi lembar laiseg terkait pelaksanaan bimbingan kelompok yang telah berlangsung. Pertemuan pertama ini diakhiri dengan salam dan doa.

2. Pertemuan Ke Dua.

Hari/Tanggal: Rabu, 28 September 2016

Waktu: 09.00-09.45 WIB Tempat: Ruang Kelas XI IPA1

Tahap permulaan ini diawali dengan salam dan doa. Pemateri mengulas sedikit tentang pertemuan yang dilaksanakan sebelumnya. Selanjutnya pemateri memberikan penjelasan tentang kegiatan yang akan dilaksanakan pada pertemuan kedua ini dengan metode ceramah dan diskusi. Pada pertemuan ini peserta didik menyepakati membahas kembali topik tentang tanggung jawab belajar.

Setiap peserta didik terlihat sangat senang. Hali ini terlihat dari hasil pengisian laiseg anggota kelompok sebagian besar menjawab sangat senang dan senang. Pada tahap akhir pemateri menyimpulkan kegiatan yang telah ditempuh dalam teknik selfmanagement. Peserta didik diminta untuk memberikan pesan dan kesan serta mengisi lembar laiseg terkait pelaksanaan layanan konseling behavioral dengan tekenik selfmangemnt yang telah berlangsung. Pada pertemuan ini peserta didik secara bersamasama saling menuliskan harapan kepada pemateri (peneliti) dan diakhiri dengan salam dan doa.

3. Pertemuan Ke Tiga

Hari/Tanggal: Selasa, 04 Oktober 2016

Waktu: 11.00-11.45 WIB, Tempat: Ruang Kelas XI IPA 1

Tahap permulaan ini diawali dengan salam dan doa. Pemateri mengulas sedikit tentang pertemuan yang dilaksanakan sebelumnya. Selanjutnya pemateri memberikan penjelasan tentang kegiatan yang akan dilaksanakan pada pertemuan kedua ini dengan metode ceramah dan diskusi. Pada pertemuan ini peserta didik menyepakati membahas kembali topik tentang tanggung jawab belajar.

Pada tahan ke tiga ini peserta didik dituntut untuk lebih aktif lagi dalam berdiskusi bagaiaman memecahkan masalah, pemateri memberikan suatu konsep yang mana untuk mengatur waktu atau mengefesienkan waktu yakni mengajak peserta didik membuat 
manajemen waktu. Pada tahap akhir pemateri menyimpulkan kegiatan yang telah ditempuh dalam teknik self- management. Peserta didik diminta untuk memberikan pesan dan kesan serta mengisi lembar laiseg terkait pelaksanaan layanan konseling behavioral dengan tekenik self-mangemnt yang telah berlangsung. Pada pertemuan terakhir ini peserta didik secara bersama-sama saling menuliskan harapan kepada pemateri (peneliti) dan diakhiri dengan salam dan doa.

4. Pertemuan Ke Empat

Hari/Tanggal: Kamis, 13 Oktober 2016

Waktu: 11.00-11.45 WIB Tempat: Ruang Kelas XI IPA 1

Tahap permulaan ini diawali dengan salam dan doa. Pemateri mengulas sedikit tentang pertemuan yang dilaksanakan sebelumnya. Selanjutnya pemateri memberikan penjelasan tentang kegiatan yang akan dilaksanakan pada pertemuan kedua ini dengan metode ceramah dan diskusi. Pada pertemuan ini peserta didik menyepakati membahas kembali topik tentang tanggung jawab belajar.

Pada tahap ke empat ini peneliti memantau hasil akhir peserta didik setelah beberapa kali menalakukan layanan dengan metode ceramah dan diskusi, guna menghasilkan data yang valid dengan posttest dengan mengunakan angket skala pskologi tanggung jawab belajar.

Setiap peserta didik terlihat sangat senang. Hali ini terlihat dari hasil pengisian laiseg anggota kelompok sebagian besar menjawab sangat senang dan senang. Pada tahap akhir pemateri menyimpulkan kegiatan yang telah ditempuh dalam teknik selfmanagement. Peserta didik diminta untuk memberikan pesan dan kesan serta mengisi lembar laiseg terkait pelaksanaan layanan konseling behavioral dengan tekenik selfmangemnt yang telah berlangsung. Pada pertemuan terakhir ini peserta didik secara bersama-sama saling menuliskan harapan kepada pemateri (peneliti) dan diakhiri dengan salam dan doa.

\section{Simpulan dan Saran}

Berdasarkan hasil penelitian bahwa Layanan Konseling Behavioral dengan Teknik Selfmanagement untuk Mengembangkan Tanggung Jawab Belajar Peserta Didik Kelas XI SMA AL-Azhar 3 Bandar Lampung Tahun Pelajaran 2016-2017 efektif dan mengalami perkembangan dalam tanggung jawab belajar baik terdapat dalam kelas eksperimen dengan diberi perlakuan teknik self-management maupun kelas kontrol dengan layanan informasi. Adapun kelas eksperimen mengalami perkembangan tanggung jawab belajar lebih tinggi daripada kelas kontrol.

Untuk guru BK, diharapkan dapat memberikan layanan yang ada dalam bimbingan dan konseling terutama layanan konseling behavioral dengan teknik self-management untuk mengembangkan tanggung jawab belajar peserta didik. Guru BK juga diharapkan lebih melakukan pendekatan dengan peserta didik agar dapat mengungkap permasalahan peserta didik secara lebih mendalam. Sementara itu, dikarenakan penelitian ini merupakan penelitian terbaru, maka untuk peneliti selanjutnya diharapkan agar lebih mendalami lagi mengenai teknik self-management dari berbagai sumber.

\section{Daftar Pustaka}

Ahmadi, Abu dan Widodo Supriyono. 2004. Psikologi Belajar. Jakarta: PT. Rineka Cipta.

Arikunto, Suharsimi. 2006. Prosedur Penelitian Suatu Pendekatan Praktik (edisi revisi VI). Jakarta: Rineka Cipta

Arintoko. 2011. Wawancara Konseling di Sekolah. Yogyakarta: Penerbit Andi

Azwar, Saifuddin. 2004. Penyusunan Skala Psikologi. Yogyakarta: Pustaka Pelajar. 
Djamarah, Syaiful Bahri dan Aswan Zain. 2010. Strategi Belajar Mengajar. Jakarta: Rineka Cipta.

Gunarsa, D. Singgih. 2004. Konseling dan Psikoterapi. Jakarta: Gunung Mulia.

Gerungan W.A. 2010. Psikologi Sosial. Bandung. Refika Aditama

Hartono dan Boy Soedarmadji. 2012. Psikologi Konseling Edisi Revisi. Jakarta: Kencana Prenada Media Group.

Komalasari, Gantina, Wahyuni dan Karsih. 2011. Teori dan Teknik Konseling. Jakarta: PT. Indeks.

Latipun. 2008. Psikologi Konseling. Malang: UMM Press.

Mappiare, Andi. 2006. Kamus Istilah Konseling \& Terapi. Jakarta: PT Raja Grafindo Persada.

Marwi, Trio Isnansyah dan Sutijono. (2012). Penggunaan Strategi Pengelolaan Diri (SelfManagement) Untuk Mengurangi Tingkat Kemalasan Belajar Pada Siswa Kelas VIII E MTs Al Rosyid Dander-Bojonegoro, Vol. 12 No. 1. Diambil di http://ppb.jurnal.unesa.ac.id/130_891/ [di akses pada tanggal 8 April 2013].

Nursalim dan Mustaji. 2010. Media BImbingan dan Konseling. Semarang: Penerbit Unesa University Press

Rusmana Nandang. 2009. Bimbingan dan Konseling kelompok di Sekolah. Bandung. Rizqi Press

Tirtarahardja umar dan Sulo S. L. 2010. Pengantar Pendidikan. Jakarta. Rineka Cipta

Sudani, dkk. 2013. Penerapan Konseling Eksistensial Humanistik Teknik Pemodelan Untuk Meningkatkan Perilaku Tanggung Jawab Belajar Siswa Kelas VIII E SMP Negeri 1 Sukasada

Diunduh dari http://ejournal.undiksha.ac.id/index.php/JJBK/article/view/765/638 pada tanggal 19 September 2013.

Sjarkawi. 2008. Pembentukan Kepribadian Anak Peran Moral, Intelektual, Emosional, dan Sosial sebagai Wujud Integritas Membangun Jati Diri. Jakarta: PT Bumi Aksara.

Sugiyono. 2012. Metode Penelitian Pendidikan Pendekatan Kuantitatif, Kualitatif, dan R\&D. Bandung: CV Alfabeta.

Syah, Muhibbin. 2003. Psikologi Belajar. Jakarta: PT. Raja Grafindo Persada. 